JEL: G31, L25

DOI: 10.5937/industrija44-9456

UDC: 005.591.4:334.7(497.11)

Short Communication

\title{
Post-acquisition organizational and portfolio restructuring and performance: Empirical evidence of acquired companies in the Republic of Serbia ${ }^{2}$
}

\author{
Article history: \\ Received: 20 November 2015 \\ Sent for revision: 23 December 2015 \\ Received in revised form: 9 June 2016 \\ Accepted: 11 June 2016 \\ Available online: 11 July 2016
}

\begin{abstract}
This paper examines the impact of post-acquisition restructuring on performance, based on a sample of Serbian acquired companies during the period 2002-2011. Using exploratory factor analysis, two new factors of postacquisition restructuring on performance were identified: the first one refers to organizational restructuring, and the second factor refers to portfolio restructuring (divestitures). By using multiple regression analysis, we tested the impact of organizational and portfolio restructuring on post-acquisition performance. The results of analysis indicate that organizational and portfolio restructuring do not have statistically significant impact on post-acquisition performance. Additionally, the results have shown that there are statistically significant differences on implemented activities of organizational restructuring between manufacturing and service sectors. Organizational restructuring was implemented to a greater extent in companies belonging to manufacturing sector than in companies belonging to service sector.
\end{abstract}

Keywords: Corporate restructuring; Corporate performance; Divestiture

\section{Postakviziciono organizaciono i portfolio restrukturiranje i performanse: Empirijska evidencija preuzetih preduzeća u Republici Srbiji}

Apstrakt: Rad istražuje uticaj postakvizicionog restrukturiranja na performanse, na primeru kompanija u Srbiji koje su bile predmet preuzimanja

\footnotetext{
${ }^{1}$ University of Kragujevac, Faculty of Economics, Serbia ssladjana@kg.ac.rs

${ }^{2}$ This work was supported by the Ministry of Education, Science and Technological

Development of the Republic of Serbia as part of research project No. 41010.
} 
Savović S.: Post-acquisition organizational and portfolio restructuring and performance

u periodu od 2002 do 2011. godine. Primenom eksplorativne faktorske analize identifikovano je dva faktora postakvizicionog restrukturiranja: prvi, koji se odnosi na organizaciono restrukturiranje $i$ drugi, koji se odnosi na portfolio restrukturiranje (dezinvestiranje). Uticaj organizacionog $i$ portfolio restrukturiranja na postakvizicione performanse testiran je primenom višestruke linearne regresije. Rezultati analize ukazuju da organizaciono $i$ portfolio restrukturiranje nema statističi značajan uticaj na postakvizicione performanse u posmatranom periodu. Dodatno, rezultati su pokazali da postoji statistička značajna razlika u implementiranim aktivnostima organizacionog restrukturiranja između proizvodnog i uslužnog sektora. Organizaciono restrukturiranje je $u$ većem stepenu implementirano $u$ kompanijama iz proizvodnog sektora.

Ključne reči: korporativno restrukturiranje; korporativne performanse; dezinvestiranje.

\section{Introduction}

Mergers and acquisitions are one of primary strategic options for companies in their attempt to secure their position in global and competitive environment. The companies make efforts to access new markets, add new capabilities, introduce new product lines and expand their knowledge base. Identifying a target company and its takeover, however, are just the start of the reorganization process that can take months or even years (Capron \& Guillen, 2009). The whole acquisition process involves reorganization of the acquired company. It is necessary to implement organizational changes on a large scale in the form of organizational restructuring in acquired company. Organizational restructuring is defined as "increasing the efficiency and effectiveness of the management team through significant changes in organizational structure"(Bowman \& Sing, 1993, p. 6). Organizational restructuring during the post-acquisition period is a complex and multidimensional process that involves decisions and affects the composition of top management team, the system of communications and coordination, the elimination of redundant activities and inefficient management practices (Capron, 1999; Datta \& Grant, 1990; Datta, 1991; Zollo \& Singh, 2004, Colombo \& Rabbiosi, 2010).

Although the integration efforts in each acquisition can largely contribute to the realization of anticipated synergies (Larsson \& Finkelstein, 1999, Zollo \& Singh, 2004), companies, particularly those that often make acquisitions, perform changes which are extensive in scope. First of all, during the postacquisition period, selling or closing of business segments which are problematic in terms of integration or are dysfunctional in terms of realizing 
synergies will be necessary (Schijven, 2005). These activities imply the implementation of portfolio restructuring. Xia and Li (2013) point out that divestitures of previously acquired units can be a useful strategic choice and that in response to the changing economic and organizational conditions, companies should implement divestitures. Other reasons for the implementation of divestitures are: increase of corporate focus, improvement of compliance and performance by removing unwanted operations from earlier acquisitions, increase financial transparency etc. (DePamphilis, 2010; Gaughan, 2002; Eckbo \& Thorbyn, 2008).

Mergers and acquisitions in the Republic of Serbia represent activities of interest to both domestic and foreign investors. Recognizing the unexploited potential of target companies, investors have acquired companies, initiating restructuring activities in post-acquisition period. Post-acquisition changes involve workforce reductions and structural redesigning with the goal of decreasing costs and redundancies and adjusting operations to the market environment (Savović, 2012). Restructuring of acquired companies encompasses asset restructuring and resource transfers (Capron \& Guillen, 2008), because they typically lack essential resources and managers with experience in competitive markets (Uhlenbruck, 2004). New owners introduce fresh capital, new technologies and new managerial know-how.

Despite intensification of mergers and acquisition in the Republic of Serbia in the last ten years, research related to this subject is still very limited. Additionally, theoretical and empirical research of restructuring activities in post-acquisition period and its effect on organizational performance is not sufficiently explored. Analysing previous experiences in the field of corporate restructuring in Serbia, Stošić (2014a) points out that unlike the developed economies as well as certain transitional economies where the intense restructuring processes yielded significant results, in Serbia these processes have been rather slow. Stošić (2014b) emphasizes unsatisfactory performances that Serbia achieves in the transition process and points out the necessity to implement restructuring of certain companies through bankruptcy and liquidation, but also the need to implement aggressive restructuring in companies that have a chance for market success. Erić, Stošić and Redžepović (2011) identify key characteristics of public enterprises restructuring processes and analyse their contribution to overall economic competitiveness in Serbia and some neighbouring countries. Nikolić and Kovačević (2014) analysed privatization effects on the organizational performance in the Republic of Serbia and emphasized that privatization partly initiated the corporate restructuring in some fields of manufacturing industry. The present study, however, makes a contribution to literature in the field of acquisitions, exploring the impact of post-acquisition restructuring on performance in acquired companies in the Republic of Serbia. 
This study offers several contributions. First, the results of this study make contributions to the literature of acquisitions expanding the existing knowledge base. Second, the study attempts to improve the understanding of the specifics of post-acquisition restructuring in the Republic of Serbia, as a transitional economy. Third, the results of this study provide a better understanding of post-acquisition restructuring, analysing whether there are differences in implemented activities of organizational restructuring between industrial sectors.

The paper is structured as follows. In the first section, we review the literature and develop hypotheses. Then we describe the research method and the data in the second section. We lastly present and discuss results of analysis.

\section{Theoretical background}

In existing literature, a generally accepted definition of corporate restructuring does not exist. DePamphilis (2010) points out that a large number of companies, especially large and highly diversified, searching for ways to increase shareholder value, continuously change the composition of their assets, liabilities, capital and operations. Bowman and Singh (1993) emphasize that the restructuring includes a wide range of transactions, including the sale of the company or acquiring other company, changing the capital structure through increased indebtedness, changing the internal organization of the company.

More holistic definition of corporate restructuring is given by Crum and Goldberg (1998) who point out that it is a "set of decisive measures taken in order to increase the competitiveness of the enterprises and thereby to enhance their value". Restructuring is a process based on an assessment of the causes of unsatisfactory performance and focused on seek ways to improve the position of the company through the change in the organizational structure, more effective management and more efficient functioning of all structures and systems in the company (Erić \& Stošić, 2013, p. 11).

Studying corporate restructuring authors highlight different classifications of restructuring. Thus, Bowman and Singh (1993) point out three ways of restructuring: portfolio restructuring - significant change in the assets of companies or lines of business, including liquidation, asset sales and the spinoffs; financial restructuring - significant changes in the capital structure of companies, including acquiring companies using debt - leveraged buyouts (LBO), intensely borrowing company with the aim of attracting cash to be distributed to shareholders - leveraged recapitalization (LB) and the conversion of debt to equity; organizational restructuring - aimed at increasing the efficiency and effectiveness of the management team through 
significant changes in the organizational structure, including changing boundaries of division, reduction of hierarchical levels, expanding the scope of control, reducing the diversification of product, management reform, reducing the number of employees. Lai and Sudarsanam (1997) point out that the companies can choose the following forms of restructuring: operational restructuring through the rationalization of costs in order to improve efficiency, strategic restructuring through the sale of assets in order to maximize cash flow, management and financial restructuring. Das, Raskhit and Debasish (2009) classify corporate restructurings as portfolio, financial, organizational, and technological restructuring (which implies an alliance with other companies in order to utilize technological expertise).

In post-acquisition period, it is necessary to implement radical changes. Postacquisition restructuring involves consolidation and restructuring of business functions, restructuring of management, labour force, and internal organizational processes, sale of a portion of company's assets, creation of a new legal subsidiary, etc. Capron and Guillen (2009) emphasize that postacquisition restructuring includes restructuring the acquired company's assets to save costs as well as transferring resources across the acquired and acquiring companies to enhance their capabilities. Restructuring the acquired company's assets refers to actions such as the disposal of some of the acquired assets, the recombination of remaining assets with changed organizational or managerial practices. Resource transfer refers to an actual transfer of technological, marketing or operational knowledge from the acquirer to the acquired company. Study by Maksimovic, Phillips and Prabhala (2011) showed that in many cases companies implemented different activities of restructuring after the acquisition. Results of this study suggest that these companies sell $27 \%$ and close $19 \%$ of plants of acquired companies within a short time after the acquisition. Acquiring companies restructure acquired companies in ways that exploit their competitive advantage. Ravenscraft and Scherer (1987) emphasized that decline in the profitability of business units usually leads to divestiture.

Colombo and Rabbiosi (2010) point out that the replacement or maintenance of top management of the acquired company is an essential dimension of post-acquisition restructuring process that affects the value creation or the development of knowledge of integrated companies. The authors stress that, in accordance with the perspective of the market for corporate control, replacement of incompetent managers can improve the efficiency of the acquired company. On the other hand, managers of acquired companies can represent a key asset that is important to preserve. Under these circumstances, the acquiring company can build or enhance competitive advantage by retaining managers who have specific and unique knowledge and skills. Meyer and Lieb-Doczy (2003) study post-acquisition restructuring of companies in transitional economies, where primarily restructuring activity 
involves reconfiguration of the production process by closing unprofitable product lines or units. As a necessity in these conditions, the authors suggest changing the configuration of resources, skills and capabilities of companies, organizational structure, etc. Companies need to build new capabilities and employees need to change their routines, patterns of interaction, attitudes and values.

It can be concluded that the post-acquisition restructuring activities, such as the reorganization of business functions, changes in the composition of the management team, downsizing, divestitures and others, focus on improving of the competitiveness of business and improving of post-acquisition performance.

Different studies have reached mixed conclusions regarding the impact of restructuring activities on performance. Certain studies show that restructuring improves performance (Bowman \& Singh, 1993; Atiase, Platt, \& Tse, 2004; Bates, 2005; Maxwell \& Rao, 2003 Maksimovic \& Philips, 2001, John \& Ofek, 1995, Denis \& Kruse 2000), while others point out that restructuring does not improve performance or even has negative effects (Brickley \& Van Drunene, 1990, Billet \& Vijh, 2004).

Atiase et al. (2004) find that the companies' earnings increase compared to the earnings levels immediately before restructuring. The authors point out that the effects are positive for companies with multiple restructurings and for companies reporting losses. Maksimovic and Philips (2001) analysed the effects of asset sales on productivity and the results of their study showed that there is an increase in productivity after implementation of restructuring. These authors concluded that the market for corporate assets facilitates the redeployment of assets from a company that does not have sufficient capacity to effectively use them, to those companies which have a greater capacity. John and Ofek (1995) studied 258 sell-off activities during 1986-1988. Their study showed that $3 / 4$ of divestiture were not the primary activities of the companies, but from the unrelated activities. These authors emphasize that, after the sale of such business segments, companies increase focus and returns for shareholders. Denis and Kruse (2000) show that companies which were restructured after they have had a significant decline in performance performed substantially better three years after the restructuring.

Some studies show that restructuring does not lead to significant improvements in performance in three to five years immediately following the restructuring (Brickley \& Van Drunene, 1990). Brickley and Van Drunene (1990) examined the impact of restructuring on shareholders' wealth and earnings. Share prices have generally increased immediately after the announcement of the restructuring, at least $1 \%$. On the other hand, companies' earnings have fallen in the short term, obviously partly due to increased cost related to the implementation of the restructuring. 
Savović S.: Post-acquisition organizational and portfolio restructuring and performance

A review of published research on the impact of restructuring on performance shows that studies that demonstrate a positive relationship between these variables dominate the literature. Accordingly, the following hypothesis is proposed:

$\mathrm{H} 1$ : Post-acquisition restructuring has a positive impact on postacquisition performance.

\section{Methods}

\subsection{Sample and procedure}

The data reported in this paper were collected as part of a larger data collection effort with aim of researching the impact of post-acquisition integration and restructuring on acquisition performance. This research was conducted in Serbian companies that were the subject of domestic and crossborder acquisitions during the period 2002-2011. The data sources for the acquired companies were The Privatization Agency of the Republic of Serbia and The Securities Commission of the Republic of Serbia. Thirty companies were selected and contacted, taking into account that the companies should be subject of domestic and cross-border acquisition and from different branches. The companies were contacted by phone, and cover letters were sent to their managers requesting them to approve distribution of the questionnaire. From the selected 30 companies, questionnaire distribution was approved in 10 companies of which 7 are production companies and 3 are in the services sector. Regarding the type of acquisition, 2 out of the 10 are domestic acquisitions and eight cases are cross-border acquisitions. Countries of acquiring companies include: Germany, Austria, Italy, Switzerland, Belgium, Norway, Greece and Serbia. Table 1 provides an overview of the sample distribution in terms of industrial branches, sectors, type of acquisitions, country of origin of acquiring companies and number of respondents in each company.

The sample covers 208 respondents $(n=208)$. In the respondent structure, $48.2 \%$ are in operating positions, and $45.1 \%$ are in managerial positions (top, middle and operative management).

The data analysis was conducted with the Statistical Package for Social Sciences - SPSS version 20.0. Exploratory factor analysis with varimax rotation was applied. Suitability of data for conducting factor analysis was tested by KMO (Kaiser-Meyer-Olkin Measure of Sampling Adequacy) and Bartlett's test. Reliability of a scale was measured by Cronbach's Alpha coefficient. Normality of distribution of research variable was tested by Kolmogorov-Smirnov test. Through applying the Mann-Whitney $U$ test, we 
Savović S.: Post-acquisition organizational and portfolio restructuring and performance

investigated whether different sectors reported statistically significant differences in implemented activities of post-acquisition restructuring. The hypotheses were tested with multiple linear regressions.

Table 1. Characteristics of companies in the sample

\begin{tabular}{|l|l|l|l|l|l|}
\hline Companies & $\begin{array}{l}\text { Industrial } \\
\text { branches }\end{array}$ & Sectors & $\begin{array}{l}\text { Type of } \\
\text { acquisition }\end{array}$ & $\begin{array}{l}\text { Country of } \\
\text { acquiring } \\
\text { company }\end{array}$ & $\begin{array}{l}\text { Number } \\
\text { of } \\
\text { respond. }\end{array}$ \\
\hline Company 1 & Pharmaceutical & Manufacturing & $\begin{array}{l}\text { Cross- } \\
\text { border }\end{array}$ & Germany & 16 \\
\hline Company 2 & $\begin{array}{l}\text { Cement } \\
\text { production }\end{array}$ & Manufacturing & $\begin{array}{l}\text { Cross- } \\
\text { border }\end{array}$ & Switzerland & 30 \\
\hline Company 3 & $\begin{array}{l}\text { Distillation, } \\
\text { purification and } \\
\text { mixing of drinks }\end{array}$ & Manufacturing & Domestic & Serbia & 21 \\
\hline Company 4 & $\begin{array}{l}\text { Food, drink and } \\
\text { tobacco retail }\end{array}$ & Service & $\begin{array}{l}\text { Cross- } \\
\text { border }\end{array}$ & Belgian & 50 \\
\hline Company 5 & $\begin{array}{l}\text { Monetary } \\
\text { operations }\end{array}$ & Service & $\begin{array}{l}\text { Cross- } \\
\text { border }\end{array}$ & Greece & 18 \\
\hline Company 6 & $\begin{array}{l}\text { Monetary } \\
\text { operations }\end{array}$ & Service & $\begin{array}{l}\text { Cross- } \\
\text { border }\end{array}$ & Austria & 11 \\
\hline Company 7 & $\begin{array}{l}\text { Milk processing } \\
\text { and cheese } \\
\text { production }\end{array}$ & Manufacturing & $\begin{array}{l}\text { Cross- } \\
\text { border }\end{array}$ & Germany & 23 \\
\hline Company 8 & $\begin{array}{l}\text { Production of } \\
\text { metal processing } \\
\text { machinery }\end{array}$ & Manufacturing & $\begin{array}{l}\text { Cross- } \\
\text { border }\end{array}$ & Norway & 10 \\
\hline Company 9 & $\begin{array}{l}\text { Distillation, } \\
\text { purification and } \\
\text { mixing of drinks }\end{array}$ & Manufacturing & Domestic & Serbia & 9 \\
\hline $\begin{array}{l}\text { Company } \\
10\end{array}$ & $\begin{array}{l}\text { Motor vehicle and } \\
\text { production }\end{array}$ & Manufacturing & $\begin{array}{l}\text { Cross- } \\
\text { border }\end{array}$ & Italy & 20 \\
\hline Total & & & & & 208 \\
\hline
\end{tabular}

Source: Author

\subsection{Measures}

Post-acquisition restructuring was measured by 5 items, based on questions such as: „After the acquisition there was replacement of one or more members of the top management team", „After the acquisition the number of employees in the company was reduced“, "After the acquisition, the company sold certain business segments". The five-degree Likert scale was used to indicate the degree of realization of a specific activity of post-acquisition restructuring. The respondents had a choice of answers from 1 - Activity was not implemented to 5 - Activity was implemented to a large extent. 
Post-acquisition performance was measured by nine items (which relate to income growth, cost reduction, productivity, market share, etc.) using subjective assessments of managers (top management, middle management, and first-line supervisors). A sample item for post-acquisition performance was "Income growth/stability is higher than prior to the acquisition" and "Productivity is higher than before the acquisition". The managers were asked to assess post-acquisition performance relative to pre-acquisition performance based on a five-point Likert scale ranging from 1 (strongly disagree) to 5 (strongly agree).

\section{Results}

\section{Preliminary analyses}

The data for factor analysis of post-acquisition restructuring were tested with the Kaiser-Meyer-Olkin measure of sampling adequacy $(K M O=0.630)$ and Bartlett's test of sphericity $(p=0.000)$. In both cases, we obtained satisfactory values. Based on results obtained from the exploratory factor analysis, we grouped variables of post-acquisition restructuring into two new factors: Organizational restructuring (significant change in the organization structure through management reform, reducing number of employees, reorganization of business functions) and Portfolio restructuring (significant change in the assets of companies, including assets sales and spin-offs), which together explain $70.23 \%$ of the total variance. Factor 1 (Organization restructuring) explains $49.11 \%$ of the total variance. Cronbach's alpha was 0.701 . Factor 2 (Portfolio restructuring) explains $21.12 \%$ of the total variance and is related to the individual consideration dimension. Cronbach's alpha was 0.739 . In both cases, an adequate level of reliability is notable among variables. The factors and their loadings are reported in Table 2.

Table 2. Factor analysis of the independent variable: post-acquisition restructuring

\begin{tabular}{|l|c|c|}
\hline & \multicolumn{2}{|c|}{ Component } \\
\cline { 2 - 3 } & 1 & 2 \\
\hline $\begin{array}{l}\text { After the acquisition procurement activities, sales, production, } \\
\text { marketing were reorganized }\end{array}$ &, $\mathbf{8 5 3}$ &, 073 \\
\hline $\begin{array}{l}\text { After the acquisition there was replacement of one or more members } \\
\text { of the top management team }\end{array}$ &, 745 &, 145 \\
\hline $\begin{array}{l}\text { After the acquisition the number of employees in the company was } \\
\text { reduced }\end{array}$ &, 731 &, 291 \\
\hline $\begin{array}{l}\text { After the acquisition, the company has made a spin-off certain } \\
\text { business segment }\end{array}$ &, 124 &, 873 \\
\hline After the acquisition, the company sold certain business segments &, 227 &, 868 \\
\hline
\end{tabular}

Source: Author's calculation 
Savović S.: Post-acquisition organizational and portfolio restructuring and performance

The data for factor analysis of post-acquisition performance were tested with the Kaiser-Meyer-Olkin measure of sampling adequacy $(K M O=0.906)$ and Bartlett's test of sphericity $(p=0.000)$. The factor analysis confirmed that all items are grouped around a single factor that explains $72.868 \%$ of the total variance. The acceptable reliability of the factor measured by Cronbach's alpha coefficient value is noticeable (Cronbach's alpha is 0.960 ).

Because the variable distribution normality test showed that there were statistically significant deviations from the normal distribution $(p=0.000)$, we used non-parametric method - Mann-Whitney $U$ test - for testing differences between manufacturing and service sectors in terms of implemented restructuring activity.

Table 3. The differences between manufacturing and service sector in terms of implemented organizational and portfolio restructuring

\begin{tabular}{|l|l|c|c|c|}
\hline & Sectors & Mean Rank & Mann-Whitney U & $\mathrm{p}$ \\
\hline $\begin{array}{l}\text { Organizational } \\
\text { restructuring }\end{array}$ & Service sector & 75,25 & \multirow{2}{*}{2791,500} & $\mathbf{2} 000$ \\
\cline { 2 - 3 } $\begin{array}{l}\text { Portfolio } \\
\text { restructuring } \\
\text { (Divestiture) }\end{array}$ & Manufacturing sector & 119,69 & \multirow{2}{*}{4562,500} & \multirow{2}{*}{, 451} \\
\cline { 2 - 3 } & Mervice sector & 98,53 & \\
\hline
\end{tabular}

Source: Author's calculation

The results of Mann-Whitney $U$ test are shown in Table 3. The analysis demonstrated that there are statistically significant differences in the case of the organizational restructuring $(p=0.00)$. The organizational restructuring (reduction of the number of employees, replacement of members of the management team, reorganization of procurement activities, sales, production, marketing) was implemented to a significant extent in companies from manufacturing sector (Mean Rank=119,69, $p<0.05$ ). The analysis revealed that there are no statistically significant differences between manufacturing and service sectors in the implemented divestiture activities $(p>0.05)$.

Table 4. The results of multiple regression analysis

\begin{tabular}{|l|c|c|c|c|}
\hline & $\mathrm{B}$ & $\mathrm{SE}$ & $\beta$ & $\mathrm{p}$ \\
\hline Organizational restructuring & 0.189 & 0.130 & 0.167 & 0.151 \\
\hline Portfolio restructuring & -0.023 & 0.087 & -0.030 & 0.794 \\
\hline R Square & & & 0.025 & \\
\hline Adjusted R Square & & & 0.002 & \\
\hline F & & & 1.107 & 0.035 \\
\hline
\end{tabular}

Source: Author's calculation 
The results of multiple regression analysis are show in Table 4. To test hypothesis, we analyse the impact of two independent variables (Organizational restructuring and Portfolio restructuring) on the dependent variable (Post-acquisition performance). The model is statistically significant $(F=1,107, p=0,035)$. The analysis showed that the impact of Organizational restructuring on Post-acquisition performance is positive and not statistically significant $(\beta=0.167, p>0.05)$. The impact of Portfolio restructuring on Postacquisition performance is negative and not statistically significant $(\beta=-0.030$, $p>0.05$ ). The coefficient of determination is 0.025 and adjusted determination coefficient was 0.002 . Hypothesis is not supported by the results.

\section{Discussions}

The research has shown that there are statistically significant differences in implemented activities of organizational restructuring between manufacturing and service sectors. The companies belonging to the service sector did not face a drastic reduction in the number of employees, major changes in the composition of management teams, as well as the reorganization of the activities of procurement, sales, and marketing. On the other hand, acquisition of companies in the manufacturing sector requires resolving the excess of employees, significant changes in business organization and composition of the management team. These results can be explained by the fact that the majority of companies from manufacturing sector, which were included in the sample, were owned by the state, facing problems of redundant employees, obsolete technology and poor organization of business activities. This situation imposed the need for implementation of more intensive postacquisition restructuring activities.

The results of multiple linear regression analysis showed that impact of organizational and portfolio restructuring on post-acquisition performance is not statistically significant. Substantial activities of organizational restructuring have been made in most of sampled companies, but the impact of this variable is not statistically significant. A possible explanation for these results could be a short period of time to achieve positive results. Organizational restructuring involves a large number of interdependent changes within the company (change in the control system, reporting relationships and job description, etc.). Consequently, a large number of established routines will probably be disrupted, and through such interruptions, a longer period of time will be required until these routines are renewed. Hence, the positive effects of post-acquisition restructuring can be expected in the long term. On the other hand, the lack of a statistically significant impact of portfolio restructuring on post-acquisition performance can be explained by the fact that these activities are implemented to a small extent in the sample companies. 


\section{Limitations and suggestions for future research}

This study provided some new insights into the performance implications of post-acquisition restructuring. However, there are some limitations, as well as avenues for future research. One of the limitations of this study is its reliance on a small sample size. For this reason, it would be interesting to test the impact of post-acquisition restructuring on performance in larger samples to see whether the relationship remains insignificant or whether it becomes significant as the sample size increases.

Another limitation of this study is related to the measurement of postacquisition performance by using the subjective assessments of managers. The most common measurements of post-acquisition performance are the accounting-based measures, stock-market-based measures and subjective assessments of managers. The application of accounting-based measures requires making comparisons of financial data prior to and after acquisitions. In this respect, there were difficulties in obtaining accounting measures of performance, especially for the period before 2005 when a centralized database of financial reports of companies in Serbia did not exist. Stock market measures of performance can be applied only in publicly quoted companies. These measures were impossible to apply because the sample included companies which are not publicly quoted. Subjective performance measures adopted in this study provided: 1) overcoming the problems of obtaining objective data and 2) a multidimensional approach to performance (estimate both financial and non-financial indicators of performance). However, it would be interesting in future research to assess the impact of postacquisition restructuring based on accounting measures (for example: average return on assets ratio- $\mathrm{ROA}$ and average return on equity ratio $\mathrm{ROE}$ ), and on stock market returns. These investigations will provide a holistic assessment effect of post-acquisition restructuring.

Furthermore, there is a need for additional empirical research which would test the process of post-acquisition restructuring with the aim of better understanding of its impact on performance. Therefore, it would be interesting to further explore whether there are statistical differences of implemented activities of post-acquisition restructuring depending on the type of acquisition (cross-border acquisitions vs. domestic acquisitions).

\section{Conclusions}

This study offers the following contributions. First, because previous research of post-acquisition restructuring and its impact on performance in the Republic of Serbia is limited, the results of this study expand the knowledge base. The 
results of multiple linear regression analysis showed that impact of organizational and portfolio restructuring on post-acquisition performance is not statistically significant. The findings suggest that a longer period of time is needed for implemented activities of post-acquisition restructuring to achieve positive effects. Second, the study attempts to improve understanding the specifics of post-acquisition restructuring in Republic of Serbia, as a transitional economy. Acquisitions in transitional economies are largely related to the privatization process. In privatized companies, it is necessary to implement radical changes, including a drastic reduction in the number of employees, major changes in the composition of management teams, structural redesigning with the goal of decreasing costs. Third, the results of this study provide a better understanding of post-acquisition restructuring, considering there are differences in implemented activities of organizational restructuring between industrial sectors. The manufacturing sector faced the need for implementation of more intensive activities of organizational restructuring in comparison with service sector. Acquiring of companies in the manufacturing sector requires resolving the excess of employees, significant changes in business organization and composition of the management team.

\section{References}

Atiase, R., Platt, D., \& Tse, S. (2004). Operational restructuring charges and postrestructuring performance. Contemporary Accounting Research, 21(3), 493-522

Bates, T.W. (2005). Asset sales, investment opportunities and the use of proceeds, Journal of Finance, 60(1), 105-135.

Billet, M., \& Vijh, A. (2004). The wealth effects of tracking stock restructurings. Journal of Financial Research, 27(4), 559-583.

Bowman, E., \& Singh, H. (1993). Corporate restructuring: Reconfiguring the Firm. Strategic Management Journal, 14(1), 5-14.

Brickley, J., \& Van Drunene, L. (1990). International corporate restructuring: An empirical analysis. Journal of Accounting and Economics, 12(1-3), 251-280.

Capron, L., \& Guillen, M. (2009). National corporate governance institutions and postacquisition target reorganization. Strategic Management Journal, 30(8), 803-833.

Capron, L. (1999). The long-term performance of horizontal acquisitions. Strategic Management Journal, 20(11), 987-1018.

Colombo, M., \& Rabbiosi, L. (2010). Technological relatedness, post-acquisition reorganization and innovation performance: looking inside the black box. Paper presented at the Summer Conference "Opening Up Innovation: Strategy, Organization and Technology“, Imperial College London Business School. Retrieved http://www2.druid.dk/conferences/viewpaper.php?id=502047\&cf=43 .

Crum, R., \& Goldberg, I. (1998). Restructuring and Managing the Enterprise in Transition, EDI Learning Resources Series, World Bank, Washington. Retrieved from http://documents.worldbank.org/curated/en/1998/07/693466/restructuringmanaging-enterprise-transition . 
Savović S.: Post-acquisition organizational and portfolio restructuring and performance

Das, B., Raskhit, D., S., \& Debasish, S. (2009). Corporate Restructuring - Merger, Acquisition and Other Forms. Mumbai: Himalaya Publishing House.

Datta, K. D. (1991). Organizational fit and acquisition performance-effects of postacquisition integration. In A. Risberg (Ed.), Mergers and Acquisitions A Critical Reader (pp.53-69). Routledge Taylor \& Francis Group, 2006.

Datta, D. K., \& Grant, J. H. (1990). Relationships between type of acquisition, the autonomy given to the acquired firm, and acquisition success: An empirical analysis. Journal of Management, 16(1), $29-44$.

Denis, D., \& Kruse, T. (2000). Managerial discipline and corporate restructuring following performance declines. Journal of Financial Economics, 55(3), 391-424.

DePamphilis, D. (2010). Mergers, acquisitions, and other restructuring activitiesintegrated approach to process, tools, cases, and solutions (5th ed.). London: Elsevier Inc.

Eckbo, E., \& Thopbupn, K. (2008). Corporate restructuring: breakups and LBOs. In E. Eckbo (Ed.), Takeover activity, valuation estimates and mergers Gains- Modern Empirical Developments, Elseiver Inc.

Erić, D., \& Stošić, I. (2013). Korporativno restrukturiranje, Beograd: Institut ekonomskih nauka, Beogradska bankarska akademija, Čigoja.

Erić, D., Stošić, I., \& Redžepović, S. (2011). Restructuring of public enterprises as source of increasing competitiveness in Serbia and South-Eastern Europe region. Paper presented at 8th International Conference - Economic integrations, competition and cooperation, section 13-Western Balkans; trade, cooperation and EU integration perspective. Retrieved from http://papers.ssrn.com/sol3/papers.cfm?abstract id=2232730 .

Gaughan, A.P. (2002). Mergers, acquisitions and corporate restructurings (3rd ed.). Hoboken, New Jersey: John Wiley \& Sons.

John, K., \& Ofek, E. (1995). Asset sales and increase in focus. Journal of Financial Economics, 37(1), 105-126.

Lai, J., \& Sudarsanam, S. (1997). Corporate Restructuring in Response to Performance Decline: Impact of Ownership, Governance and Lenders, European Finance Review, 1(2), 197-233.

Larsson, R., \& Finkelstein, S. (1999). Integrating strategic, organizational, and human resource perspectives on mergers and acquisitions: A case survey of synergy realization. Organization Science, 10(1), 1-26.

Maksimovic, V., \& Phillips, G. (2001). The market for corporate assets: Who engages in mergers and asset sales and are there efficiency gains? Journal of Finance, 56(6), 2019-2065.

Maksimovic, V., Phillips, G., \& Prabhala. N. (2011). Post-merger restructuring and the boundaries of the firm. Journal of Financial Economics, 102(2), 317-343.

Maxwell, W.,\& Rao, R. (2003). Do spin-offs expropriate wealth from bondholders? Journal of Finance, 58(5), 2087-2108.

Meyer, K., \& Lieb-Doczy, E. (2003). Post-acquisition restructuring as evolutionary process. Journal of Management Studies, 40(2), 459-482.

Nikolić, I., \& Kovačević, M. (2014). Efekti privatizacije - empirijska analiza i rezultati na srpsku industriju, Industrija, 42(1), 63-86.

Ravenscraft, D., \& Scherer, F. (1987). Life after takeover. Journal of Industrial Economics, 36(2), 147-156.

Savović, S. (2012). Značaj postakvizicione integracije za kreiranje vrednosti i uspeh merdžera i akvizicija. Ekonomski horizonti, 14(3), 193-205. 
Savović S.: Post-acquisition organizational and portfolio restructuring and performance

Schijven, M. (2005). Curing the firm's indigestion: organizational restructuring and dynamics of acquisition performance. Academy of Management Best Conference Paper 2005, BPS:M1, Honolulu, HI, USA.

Stošić, I. (2014a). Korporativno restrukturiranje preduzeća u svetu i Srbiji, Poslovna ekonomija, 8(1), 157-176.

Stošić, I. (2014b). The challenges of defining and implementing corporate restructuring programs, Economic Themes, 52(2), 139-153.

Uhlenbruck, K. (2004). Developing acquired foreign subsidiaries: the experience of MNEs in transition economies, Journal of International Business Studies, 35(2), 109-123.

Xia, J., \& Li, S. (2013). The divestiture of acquired subunits: a resource dependence approach. Strategic Management Journal, 34(2), 131-148.

Zollo, M., \& Singh, H. (2004). Deliberate learning in corporate acquisitions: Postacquisition strategies and integration capability in US bank mergers. Strategic Management Journal, 25(13), 1233-1256. 